\title{
ANALISIS PERHITUNGAN DAN PELAPORAN PAJAK PERTAMBAHAN NILAI PADA PT. INDUSTRI KAPAL INDONESIA (PERSERO) DI MAKASSAR
}

\author{
Mira $^{1}$, Muhammad Rusydi², Muh Alfian ${ }^{3}$ \\ Universitas Muhammadiyah Makassar \\ Email: ${ }^{1}$ mira@unismuh.ac.id, ${ }^{2}$ muhammadrusyidi@unismuh.ac.id, ${ }^{3}$ muhalfian@unismuh.ac.id
}

\begin{abstract}
This study aims to determine the calculation and reporting of value added tax applied at PT. Indonesian Ship Industry, Persero. The type of research used in this study is case study research with qualitative and quantitative approaches. The processed data is data in the form of the amount of input VAT and output VAT presented over the past five years as well as the results of interviews related to value added tax reporting procedures. The data analysis technique used in the study was using comparative descriptive analysis by recording input and output VAT, comparing input and output VAT with VAT period SPT, comparing recording with VAT Law and drawing conclusions from the results of the analysis.
\end{abstract}

Keywords: VAT Calculation, VAT reporting

\begin{abstract}
Penelitian ini bertujuan untuk mengetahui perhitungan dan pelaporan pajak pertambahan nilai yang di terapkan di PT. Industri Kapal Indonesia, Persero.Jenis penelitian yang digunakan dalam penelitian adalah penelitian studi kasus dengan pendekatan kualitatif dan kuantitatif. Data yang diolah adalah data berupa jumlah PPN masukan dan PPN keluaran yang disajikan selama lima tahun terakhir serta hasil wawancara terkait prosedur pelaporan pajak pertambahan nilai. Teknik analisis data yang digunakan dalam penelitian adalah menggunakan analisis deskriptif komparati fdengan cara Mendata PPN masukan dan keluaran, Membandingkan PPN masukan dan keluaran dengan SPT Masa PPN, Membandingkan pencatatan dengan UU PPN kemudian menarik kesimpulan dari hasil analisis tersebut.
\end{abstract}

Keywords: Perhitungan PPN, Pelaporan PPN 


\section{PENDAHULUAN}

Pajak merupakan kewajiban yang harus dibayar oleh masyarakat baik pribadi maupun badan dari pendapatan atau penghasilannya kepada Pemerintah ditujukan untuk kegiatan pembangunan di segala bidang. Kegiatan pembangunan di berbagai sektor pada umumnya bermaksud untuk meningkatakan harkat bangsa dan juga kesejahteraan masyarakatnya.

Sesuai dengan ketentuan pasal 23 ayat (2) UUD 1945, pemungutan pajak harus didasarkan pada undang-undang perpajakan yang disusun oleh pemerintah dan disetujui oleh rakyatnya melalui Dewan Perwakilan Rakyat (DPR). Untuk itu dasar Pajak Pertambahan Nilai adalah Undang-undang Republik Indonesia Nomor 42 Tahun 2009 tentang Perubahan Ketiga atas Undang-undang Nomor 8 Tahun 1983 tentang Pajak Pertambahan Nilai Barang dan Jasa dan Pajak Penjualan atas Barang Mewah.

Pajak Pertambahan Nilai (PPN) untuk pertama kali diperkenalkan oleh Carl Friedrich von Siemens,seorang industrialis dan konsultan pemerintah Jerman pada tahun 1919 karena pada saat itu pemerintah jerman mengalami krisis keuangan akibat terlibat dalam perang dunia I. Namun justru pemerintah perancis yang pertama kali menerapakan PPN dalam perpajakan pada tahun 1945, sedangkan Jerman menerapkannya pada awal tahun 1968. Indonesia sendiri baru mengadopsi PPN pada tanggal 1 april 1985 menggantikan Pajak Penjualan (PPn) yang sudah berlaku di Indonesia sejak tahun 1951.

PPN merupakan pajak yang dikenakan atas konsumsi barang atau jasa dalam negeri (dalam Daerah Pabean). Pajak Pertambahan Nilai (PPN) timbul karena dikenakan faktor-faktor produksi pada tiap perusahaan dalam menyiapkan, menghasilkan menyalurkan dan memperdagangkan barang atau pemberian jasa kepada konsumen yang dipungut secara tidak langsung. Selain itu PPN merupakan pajak yang dipungut oleh pemerintahan pusat dan digunakan untuk membiayai rumah tangga negara (pajak pusat).

PT Industri Kapal Indonesia Makassar adalah perusahaan yang bergerak di jasa manufaktur, dimana PT IKI selain menyediakan jasa perbaikan kapal juga memproduksi kapal berdasarkan pesanan. Ditinjau dari kegiatan usahanya, PT IKI melakukan kegiatan perdagangan yang dikenakan PPN. Bila perusahaan melakukan pembelian terhadap BKP maka dikenakan PPN masukan dari Dasar DPP barang tersebut. Sebaliknya bila perusahaan ini melakukan penjualan terhadap barang tersebut, maka perusahaan berhak melakukan pemungutan PPN keluaran terhadap BKP tersebut.

Permasalahan yang timbul dalam perhitungan PPN baik yang lebih bayar maupun yang kurang bayar adalah membandingkan antara Pajak Masukan yang merupakan kredit pajak dan dengan Pajak Keluaran yang merupakan hutang pajak, atau perhitungan tidak disesuaikan dengan perundang-undangan yang berlaku. Selanjutnya dalam pembuatan faktur pajak dapat dibuat pada akhir bulan setelah penyerahan Barang Kena Pajak.Pada saat penyerahan Barang Kena Pajak, PPN nya belum terutang sehingga belum dicatat dan yang dilaporkan dalam SPT Masa hanya yang terhitung saja. Dalam pelaporan, keterlambatan dokumen sebagai bukti dalam Pajak Masukan dan Pajak Keluaran sehingga Pelaporan Pajak Masukan dan Pajak Keluaran tidak pada masa pajak yang bersangkutan.

\section{TINJAUAN PUSTAKA}

\section{Pengertian Pajak}

Waluyo (2010: 3) menyatakan bahwa pajak adalah iuran wajib berupa uang atau barang yang dipungut oleh penguasa berdasarkan norma-norma hukum guna menutup biaya produksi barang-barang dan jasa-jasa kolektif dalam mencapai kesejahteraan umum. Menurut Diana (2013:37) pajak memiliki 2 fungsi utama, diantaranya:

a. Fungsi Penerimaan (Budgeter)

Fungsi penerimaan yaitu sebagai alat (sumber untuk memasukan uang sebanyakbanyaknya dalam kas negara dengan tujuan untuk membiayai pengeluaran negara yaitu pengeluaran rutin dan pembanguanan. Sebagai sumber pendapatan negara pajak berfungsi untuk membiayai pengeluaran-pengeluaran negara. Untuk menjalankan tugas-tugas rutin negara dan melaksanakan pembangunan negara membutuhkan biaya. Biaya ini dapat diperoleh dari penerimaan pajak. Pajak digunakan untuk pembiayaan rutin seperti belanja pegawai, belanja barang, pemeliharaan, dan lain sebagainya. Untuk pembiayaan pembangunan, uang dikeluarkan dari tabungan pemerintah 
yakni penerimaan dalam negeri dikurangi pengeluaran rutin. Tabungan pemerintah ini dari tahun ke tahun harus ditingkatkan sesuai kebutuhan pembiayaan pembangunan yang semakin meningkat dan ini terus diharapkan dari sektor pajak.

\section{b. Fungsi Mengatur (Regulerend)}

Fungsi mengatur yaitu sebagai alat untuk mencapai tujuan tertentu di bidang keuangan (umpamanya bidang ekonomi, politik, budaya, pertahanan keamanan misalnya: mengadakan perubahan tarif, memberikan pengecualianpengecualian, keringanan-keringanan atau sebaliknya pemberatan-pemberatan yang khusus ditunjukan kepada masalah tertentu. Pemerintah bisa mengatur pertumbuhan ekonomi melalui kebijaksanaan pajak. Dengan fungsi mengatur, pajak bisa digunakan sebagai alat untuk mencapai tujuan. Pelaksanaan fungsi ini bisa positif dan negatif. Pelaksanaan fungsi pajak yang positif maksudnya jika suatu kegiatan yang dilakukan masyarakat oleh pemerintah di pandang sebagai sesuatu yang positif, oleh karena itu didorong oleh pemerintah dengan memberikan dorongan berupa insentif pajak (tax incentive) yang dilakukan dengan cara pemberian fasilitas perpajakan. Sementara itu, pelaksanaan fungsi mengatur yang bersifat negatif dimaksudkan untuk mencegah atau menghalangi perkembangan yang menjuruskan kehidupan masyarakat ke arah tujuan tertentu. Hal itu dapat dilakukan dengan membuat peraturan di bidang perpajakan yang menghambat dan memberatkan masyarakat untuk melakukan suatu kegiatan yang ingin di berantas oleh pemerintah.

Selain dua fungsi diatas, menurut Diana (2013:38) pajak juga memiliki fungsi lain yaitu:

a. Fungsi Stabilitas

Dengan adanya pajak, pemerintah memiliki dana untuk menjalankan kebijakan yang berhubungan dengan stabilitas harga sehingga inflasi dapat dikendalikan. Hal ini bisa dilakukan antara lain dengan jalan mengatur pereedaran uang di masyarakat, pemungutan pajak, penggunaan pajak yang efektif dan efisien

b. Fungsi Redistribusi

Pendapatan Pajak yang sudah dipungut oleh negara akan digunakan untuk membiayai semua kepentingan umum, termasuk juga untuk membiayai pembangunan sehingga dapat membuka kesempatan kerja, yang pada akhirnya akan meningkatkan pendapatan masyarakat.

c. Fungsi Demokrasi

Pajak yang sudah dipungut oleh negara merupakan wujud sistem gotong royong. Fungsi ini dikaitkan dengan tingkat pelayanan pemerintah kepada masyarakat pembayar pajak d. Jenis Pajak

Menurut Resmi (2014:7) terdapat beberapa jenis pajak yang dapat di kelompokan menjadi tiga yaitu menurut golongan, menurut sifat, dan menurut lembaga pemungutnya.

Menurut golongan, pajak dapat dikelompokkan menjadi:

a. Pajak langsung adalah pajak yang harus dipikul atau ditanggung sendiri oleh Wajib Pajak dan tidak dapat dilimpahkan atau dibebankan kepada orang lain atau pihak lain, pajak harus menjadi beban Wajib Pajak yang bersangkutan. Contoh: pajak Penghasilan $(\mathrm{PPh}), \mathrm{PPh}$ dibayar atau ditanggungoleh pihak-pihak tertentu yang memperoleh penghasilan tersebut.

b. Pajak tidak langsung adalah pajak yang pada akhirnya dapat dibebankan atau dilimpahkan kepada orang lain atau pihak ketiga. Pajak tidak langsung terjadi jika terdapat suatu kegiatan, peristiwa, atau perbuatan yang menyebabkan terutangnya pajak, misalnya terjadi penyerahan barang atau jasa. Contoh: Pajak Pertambahan Nilai (PPN), PPN terjadi karena terjadi pertambahan nilai terhadap barang atau jasa. Pajak ini dibayarkanoleh produsen atau pihak yang menjual barang tetapi dapat dibebankan kepada konsumen.

Menurut sifatnya, pajak dapat dikelopokkan menjadi dua, yaitu:

a. Pajak subjektif yaitu pajak yang pengenaannya memperhatikan keadaan pribadi Wajib Pajak atau pengenaan pajak yang memerhatikan subjeknya, contoh: Pajak Penghasilan (PPh). Dalam $\mathrm{PPh}$ terdapat Subjek Pajak (Wajib Pajak) orang pribadi. Pengenaan $\mathrm{PPh}$ untuk orang pribadi tersebut memperhatikan keadaan pribadi Wajib Pajak (status perkawinan), banyaknya anak, tanggungan, dan lainnya yang selanjutnya digunakan untuk menentukan besarnya Penghasilan Tidak Kena Pajak (PTKP). 
b. Pajak objektif merupakan pajak yang pengenaannya memerhatikan objeknya baik berupa benda, keadaan, perbuatan, atau peristiwa yang mengakibatkan timbulnya kewajiban membayar pajak, tanpa memerhatikan keadaan pribadi Subjek Pajak (Wajib Pajak) maupun tempat tinggal. Contoh: Pajak Pertambahan Nilai (PPN) dan Pajak atas Barang Mewah (PPnBM), serta Pajak Bumi dan Bangunan.

Menurut Lembaga Pemungut, dibagi menjadi dua yaitu :

a. Pajak Pusat adalah pajak yang dipungut oleh pemerintah pusat dan digunakan untuk membiayai rumah tangga negara, contohnya Pajak Bumi dan Bangunan (PBB), PPh, PPN, PPnBM dan Bea Materai.

b. Pajak Daerah adalah pajak yang dipungut oleh pemerintah daerah untuk membiayai rumah tangga daerah, contohnya Pajak Reklame.

\section{Sistem Pemungutan Pajak}

Dalam melakukan pembayaran pajak, pemerintah dan wajib pajak perlu mengetahui apa saja jenis sistem pemungutan pajak dan sistem apa yang berlaku di Indonesia. Jenisjenis sistem pengenaan pajak dapat dibagi menjadi seberapa bagian, yaitu Sistem pemungutan pajak yang memberi kewenangan aparatur perpajakan untuk menentukan sendiri jumlah pajak yang terutang setiap tahunnya sesuai dengan peraturan perundang-undangan perpajakan yang berlaku. Dalam sistem ini, inisiatif serta kegiatan menghitung dan memungut pajak sepenuhnya berada di tangan para aparatur perpajakan. Dengan demikian, berhasil atau tidaknya pelaksanaan pemungutan pajak banyak tergantung pada aparatur perpajakan(peranan dominan ada pada aparatur perpajakan).

\section{a. Self Assesment System}

Sistem pemungutan pajak yang memberi wewenang Wajib Pajak dalam menentukan sendiri jumlah pajak yang terutang setiap tahunnya sesuai dengan peraturan perundangundangan perpajakan yang berlaku. Dalam sistem ini, inisiatif serta kegiatan menghitung dan memungut pajak sepenuhnya berada di tangan Wajib Pajak. Wajib Pajak dianggap mampu menghitung pajak, mampu memahami undang-undang perpajakan yang sedang berlaku, dan mempunyai kejujuran yang tinggi, serta menyadari akan arti pentingnya membayar pajak. Oleh karena itu, Wajib Pajak di beri kepercayaan untuk :

1) Menghitung sendiri pajak yang terutang

2) Memperhitungkan sendiri pajak yang terutang

3) Membayar sendiri jumlah pajak yang terutang; dan

4) Mempertanggungjawabkan pajak yang terutang.

Dengan demikian, berhasil atau tidaknya pelaksanaan pemungutan pajak banyak bergantung pada Wajib Pajak sendiri(Peran dominan ada pada Wajib Pajak).

\section{b. Withholding Tax System}

Sistem pemungutan pajak yang memberi wewenang kepada pihak ketiga yang ditunjuk untuk menentukan besarnya pajak yang terutang oleh Wajib Pajak sesuai dengan peraturan perundang-undangan perpajakan yang berlaku. Penunjukan pihak ketiga ini dilakukan sesuai dengan peraturan perundang-undangan perpajakan, keputusan modern dan peraturan lainnya

\section{Konsep pajak pertambahan nilai}

Pajak Pertambahan Nilai merupakan pengganti dari Pajak Penjualan. Halini disebabkan karena Pajak Penjualan dirasa sudah tidak lagi memadai untukmenampung kegiatan masyarakat dan belum mencapai sasaran kebutuhanpembangunan, antara lain untuk meningkatkan penerimaan negara, mendorongekspor, dan pemerataan pembebanan pajak. Berdasarkan UU PPN No.42 Tahun 2009, istilah umum yang digunakan terkait Pajak Pertambahan Nilai adalah:

a. Daerah Pabean adalah wilayah Republik Indonesia yang meliputi wilayah darat, perairan, dan ruang udara diatasnya, serta tempat-tempat tertentu di Zona Ekonomi Eksklusif dan landas kontinen yang di dalamnya berlaku Undang-Undang yang mengatur mengenai kepabeanan.

b. Barang adalah barang berwujud, yang menurut sifat atau hukumnya dapat berupa barang bergerak atau barang tidak bergerak, dan barang tidak berwujud.

c. Barang Kena Pajak adalah barang yang dikenai pajak berdasarkan Undang-undang ini.

d. Penyerahan Barang Kena Pajak adalah setiap kegiatan penyerahan Barang Kena Pajak. 
e. Jasa adalah setiap kegiatan pelayanan yang berdasarkan suatu perikatan atau perbuatan hukum yang menyebabkan suatu barang, fasilitas, kemudahan atau hak tersedia untuk dipakai, termasuk jasa yang dilakukan untuk menghasilkan barang karena pesanan atau permintaan dengan bahan dan atas petunjuk dari pemesan.

f. Jasa Kena Pajak adalah jasa yang dikenai pajak berdasarkan Undang-undang ini.

g. Penyerahan Jasa Kena Pajak adalah setiap kegiatan pemberian Jasa Kena Pajak.

h. Pemanfaatan Jasa Kena Pajak dari luar Daerah Pabean adalah setiap kegiatan pemanfaatan Jasa Kena Pajak dari luar Daerah Pabean di dalam Daerah Pabean.

i. Impor adalah setiap kegiatan memasukkan barang dari luar Daerah Pabean ke dalam Daerah Pabean.

j. Pemanfaatan Barang Kena Pajak Tidak Berwujud dari luar Daerah Pabean adalah setiap kegiatan pemanfaatan Barang Kena Pajak Tidak Berwujud dari luar Daerah Pabean di dalam Daerah Pabean.

k. Ekspor Barang Kena Pajak Berwujud adalah setiap kegiatan mengeluarkan Barang Kena Pajak Berwujud dari dalam Daerah Pabean ke luar Daerah Pabean.

1. Perdagangan adalah kegiatan usaha membeli dan menjual, termasuk kegiatan tukar menukar barang, tanpa mengubah bentuk atau sifatnya.

m. Badan adalah sekumpulan orang dan/atau modal yang merupakan kesatuan baik yang melakukan usaha maupun yang tidak melakukan usaha yang meliputi perseroan terbatas, perseroan komanditer, perseroan lainnya, badan usaha milik negara atau badan usaha milik daerah dengan nama dan dalam bentuk apapun, firma, kongsi, koperasi, dana pensiun, persekutuan, perkumpulan, yayasan, organisasi massa, organisasi sosial politik, atau organisasi lainnya, lembaga dan bentuk badan lainnya termasuk kontrak investasi kolektif dan bentuk usaha tetap.

n. Pengusaha adalah orang pribadi atau badan dalam bentuk apa pun yang dalam kegiatan usaha atau pekerjaannya menghasilkan barang, mengimpor barang, mengekspor barang melakukan usaha perdagangan, memanfaatkan barang tidak berwujud dari luar Daerah Pabean, melakukan usaha jasa termasuk mengekspor jasa, atau memanfaatkan jasa dari luar Daerah Pabean.

o. Pengusaha Kena Pajak adalah pengusaha yang melakukan penyerahan Barang Kena Pajak dan/atau penyerahan Jasa Kena Pajak yang dikenai pajak berdasarkan undangundang ini.

\section{Penelitian Terdahulu}

Bebarapa penelitian terdahulu yang berkaitan dengan analisis perhitungan dan pelaporan pajak pertambahan nilai adalah sebagai berikut :

Rendy Daryl Pandelak (2013) melakukan penelitian tentang Analisis Perhitungan Dan Pelaporan Pajak Pertambahan Nilai Pada Pt. Maber Teknindo, dari hasil penelitian tersebut diketahui bahwa perusahaan telah melaksanakan kewajibannya dalam hal perhitungan dan pelaporan PPN selama satu tahun.Mekanisme penerbitan faktur pajak juga telah berdasarkan peraturan perpajakan. Mekanisme pengkreditan dilakukan pada setiap akhir bulan dengan membandingkan pajak masukan yang diperoleh melalui bukti faktur pajak dengan pajak keluaran yang sudah dipungut dengan bukti faktur pajak.Kesalahan yang terjadi pada PT Maber Teknindo adalah dalam hal penyetoran dan pelaporan SPT Masa PPN dimana masih sering terjadi keterlambatan.

Juvenalis Paulus Sepang, Ventje Ilat dan Lidia Mawikere (2014) melakukan penelitian tentang Perhitungan pencatatan dan pelaporan pajak pertambahan nilai Pada pt. Simple jaya manado, dari hasil penelitian tersebut diketahui bahwa perusahaan telah melakukan perhitungan, pencatatan, dan pelaporan dengan baik dan benar sesuaidengan peraturan yang berlaku. Manajemen perusahaan melakukan pengurangan antara pajak keluaran denganpajak masukan, dikarenakan perusahaan mengalami kurang bayar akibat pajak keluaran lebih besar dari padapajak masukan.

Marindo Putra (2016) melakukan penelitian tentang analisis perhitungan dan pelaporan pajak pertambahan nilai pada pt fajar mas karyatama, dari hasil penelitian tersebut diketahui bahwa Hampir tiap bulan perusahaan membuat pembetulan atas SPT Masa PPN karena adanya keterlambatan pemberian Faktur Pembelian dari Pimpinan Cabang ke staf yang menangani Pajak. Perusahaan dalam melakukan penjualan Barang Kena Pajak tidak menerbitkan Faktur Pajak Keluaran, kecuali 
jika costumer atau pembeli membutuhkan Faktur atas pembelian yang dilakukan.

$$
\text { Juniaty Carmila Manarisip (2013) }
$$
melakukan penelitian tentang evaluasi perhitungan, pencatatan, pelaporan ppn pt. swa karya muda balikpapan, dari hasil penelitian tersebut diketahui bahwa penghitungan Pajak Pertambahan Nilai pada PT. Swa Karya Muda telah dilakukan dengan benar dan sesuai dengan Ketentuan Perpajakan yang berlaku. Pencatatan yang dilakukan oleh PT. Swa Karya Muda sudah cukup baik dan memadai untuk menghasilkan informasi bagi perusahaan agar dapat melakukan perhitungan pajak yang terutang maupun untuk pelaporan SPT Masa PPN. Sedangkan untuk pelaporan, SPT Masa PPN PT. Swa Karya Muda telah diisi dengan lengkap, benar, jelas dan bersih dari coretan.

Simarmata (2010) melakukan penelitian tentang analisis perhitungan dan pelaporan Pajak pertambahan nilai pada Pt. Masaji tatanan container, dari hasil penelitian tersebut diketahui bahwa telah melaksanakan kewajibannya dalam halperhitungan dan pelaporan Pajak Pertambahan Nilai selama satu tahun untuk. Kesalahan yang terjadi pada tagihan yang dibuat PT. Masaji Tatanan Container, dimana adanya data - data yang tidak valid untuk keperluan perhitungan Pajak Pertambahan Nilai. Selain hal tersebut, keterlambatan perincian biaya yang dikenakan pajak pertambahan nilai dari operasional menyebabkan pajak masukan tidak dikreditkan pada masa pajak yang bersangkutan. PT. Masaji Tatanan Container juga tidak melaporkan Pajak Masukan yang dipungut dengan Faktur Pajak Sederhana.

\section{METODE}

Penelitian ini merupakan jenis penelitian kualitatif dan kuantittatif. Data kualitatif adalah data yang disajikan dalam bentuk uraian deskriptif mengenai gambaran umum dan sebagainya. Data kualitatif yang digunakan dalam penelitian ini mengenai kondisi perusahaan misalnya profil perusahaan, sedangkan data kuantitatif merupakan data yang disajikan dalam bentuk angka-angka dan tabel. Dalam penelitian ini data kuantitatif yang digunakan yaitu data penjualan dan pembelian dari PT. Industri kapal Indonesia (persero)

Penelitian ini berfokus pada analisis perhitungan dan pelaporan pajak pertambahan nilai pada PT. Industri Kapal Indonesia (persero).

Perusahaaan yang menjadi objek penelitian adalah PT. Industri Kapal Indonesia (persero), yang beralamatkan di Jln. Galangan kapal No. 31 Makassar, Sulawesi Selatan. Waktu penelitian dan pengambilan data dilakukan selama dua bulan yaitu mulai dari bulan April 2018 dan Mei 2018.

Sumber data yang dikumpulkan dalam penelitian ini adalah data primer (Primary Data), yaitu data yang diperoleh langsung dari perusahaan seperti : sejarah perusahaan, struktur organisasi, dan informasi lain yang berkaitan dengan penelitian. Dan data Sekunder (Secondary Data), yaitu data yang diperoleh dari makalah ilmiah dan data kepustakaan.

Penelitian adalah observasi/pengamatan dan studi kasus karena membandingkan antara teori dan praktek sehingga untuk mendapatkan data atau bahan penulisan ini, peneliti mengumpulkan data dengan menggunakan metode penelitian sebagai berikut:

a. Observasi

Teknik observasi dilakukan dengan mengadakan pengamatan secara langsung pada objek penelitian yaitu PT. Industri Kapal Indonesia (persero), Makassar

b. Interview

Teknik interview yaitu dilakukan dengan jalan mengadakan wawancara secara langsung dengan bagian perpajakan pada PT. Industri kapal indonesia

c. Dokumentasi

Dokumentasi yaitu pemanfaatan informal melalui dokumen-dokumen tertentu yang dianggap pendukung dan bersumber dari laporan-laporan yang berkaitan perhitungan dan pelaporan pajak pertambahan nilai.

Metode yang digunakan adalah metode analisis deskriptif komparatif yaitu suatu metode pembahasan masalah yang sifatnya membandingkan variabel yang sama untuk sampel yang berbeda atau dapat digunakan untuk membandingkan variabel yang berbeda untuk sampel yang sama. Komparatif yang membandingkan perhitungan dan pelaporan Pajak Pertambahan Nilai (PPN) yang dilakukan oleh PT Industri Kapal Indoensia (persero), Kota Makassar dengan perhitungan dan pelaporan Pajak Pertambahan Nilai (PPN) menurut UU PPN No.42 tahun 2009 lalu mengajukan kesimpulan yang logis berdasarkan 
hasil penelitian tersebut dan memberikan saransaran.

\section{HASIL DAN PEMBAHASAN}

\section{Hasil}

Pajak masukan dikenakan ketika Pengusaha Kena Pajak melakukan pembelian terhadap barang kena pajak atau jasa kena pajak. PT. Industri Kapal Indonesia juga melakukan pembelian terhadap barang kena pajak selama lima tahun berturut-turut mulai dari tahun 2013 sampai 2017. Sumber : Data PT. Industri kapal Indonesia 2018 (diolah) Berdasarkan tabel 4.1 diatas yang diolah oleh penulis maka diperoleh DPP untuk bulan Januari sebesar Rp. 650.063.850,00 dengan PPN sebesar Rp. 65.006.385,00.Selanjutnya DPP untuk Februari Rp. 931.828.398,00 dengan PPN sebesar Rp. 93.182.839,80, DPP untuk bulan Maret sebesar Rp. 94.129.273,00 dengan PPN Sebesar Rp. 9.412.927,30, DPP untuk April Rp. 35.848.000,00 dengan PPN sebesar Rp.
3.584.800,00 , DPP untuk bulan Mei sebesar Rp. 463.991.500,00 dengan PPN Sebesar Rp. 46.399.150,00, DPP untuk bulan Juni sebesar Rp. 4.840.000,00 dengan PPN Sebesar Rp.484.000,00, DPP untuk bulan Juli sebesar Rp1.468.211.837,00 dengan PPN Sebesar Rp. 146.821.183,70, DPP untuk bulan Agustus sebesar Rp. 40.810.000,00 dengan PPN Sebesar Rp. 4.081.000,00, DPP untuk bulan September sebesar Rp. 52.345.100,00 dengan PPN Sebesar Rp. 5.234.510,00, DPP untuk bulan Oktober sebesar Rp. 270.328.800,00 dengan PPN Sebesar Rp. 27.032.880,00, DPP untuk bulan November sebesar Rp. 739.588.950,00 dengan PPN Sebesar 73.958.895,00, dan DPP untuk bulan Desember sebesar Rp. 12.076.924.868,00 dengan PPN Sebesar Rp. 1.207.692.486,80. Dengan demikian total DPP untuk tahun 2013 adalah sebesar Rp. 16.828.910.576,00 dengan PPN sebesar Rp. 1.682.891.057,60.

a. PPN Masukan / Data Pembelian 2014

Tabel 1. Data Pembelian (PM) PT. IKI 2014

\begin{tabular}{llllll}
\hline No & Bulan & Periode & Dpp & Ppn & Jumlah \\
\hline 1 & Januari & 31-Jan-14 & $282.079 .500,00$ & $28.207 .950,00$ & $310.287 .450,00$ \\
\hline 2 & Februari & 28-Feb-14 & 1.787 .841 .100$, & 178.784 .110$, & 1.966 .625 .210$, \\
\hline 3 & Maret & 31-Mar-14 & $806.445 .908,00$ & $80.644 .590,80$ & $887.090 .498,80$ \\
\hline 4 & April & 30-Apr-14 & $846.502 .512,00$ & $84.650 .251,20$ & $931.152 .763,20$ \\
\hline 5 & Mei & 31-Mei-14 & 1.736 .842 .450$, & $173.684 .245,0$ & 1.910 .526 .695$, \\
\hline 6 & Juni & 30-Jun-14 & 1.111 .515 .650$, & $111.151 .565,0$ & 1.222 .667 .215$, \\
\hline 7 & Juli & 31-Jul-14 & 15.984 .715 .205 & 1.598 .471 .520$, & $17.583 .186 .725,50$ \\
\hline 8 & Agustus & 31-Agt-14 & $7.944 .487 .111,00$ & $794.448 .711,10$ & $8.738 .935 .822,10$ \\
\hline 9 & September & 30-Sep-14 & $1.807 .540 .150,00$ & $180.754 .015,00$ & $1.988 .294 .165,00$ \\
\hline 10 & Oktober & 31-Okt-14 & $8.380 .089 .811,00$ & $838.008 .981,10$ & $9.218 .098 .792,10$ \\
\hline 11 & November & 30-Nov-14 & $2.475 .384 .509,00$ & $247.538 .450,90$ & $2.722 .922 .959,90$ \\
\hline 12 & Desember & 31-Des-14 & $3.589 .934 .742,00$ & $358.993 .474,20$ & $3.948 .928 .216,20$ \\
\hline Jumlah & 46.753.378.648,00 & 4.675.337.864,80 & $51.428 .716 .512,80$ & & \\
\hline
\end{tabular}

Sumber : Data PT. Industri kapal Indonesia (diolah)

Berdasarkan tabel 1. diatas yang diolah oleh penulis maka diperoleh DPP untuk bulan Januari sebesar Rp. 282.079.500,00 dengan PPN sebesar Rp. 28.207.950,00. Selajutnya DPP untuk Februari Rp. 1.787.841.100,00 dengan PPN sebesar Rp. 178.784.110,00, DPP untuk bulan Maret sebesar Rp. 806.445.908,00 dengan PPN Sebesar Rp. 80.644.590,80, DPP untuk April Rp. 846.502.512,00 dengan PPN sebesar Rp. 84.650.251,20, DPP untuk bulan Mei sebesar Rp. 1.736.842.450,00 dengan PPN Sebesar Rp. 173.684.245,00, DPP untuk bulan Juni sebesar Rp. 1.111.515.650,00 dengan PPN Sebesar Rp.111.151.565,00, DPP untuk bulan Juli sebesar
Rp. 15.984.715.205,00 dengan PPN Sebesar Rp.1.598.471.520,50, DPP untuk bulan Agustus sebesar Rp. 7.944.487.111,00 dengan PPN Sebesar Rp. 794.448.711,10, DPP untuk bulan September sebesar Rp. 1.807.540.150,00 dengan PPN Sebesar Rp. 180.754.015,00, DPP untuk bulan Oktober sebesar Rp. 8.380.089.811,00 dengan PPN Sebesar Rp. 838.008.981,10, DPP untuk bulan November sebesar Rp. 2.475.384.509,00 dengan PPN Sebesar Rp. 247.538.450,90, dan DPP untuk bulan Desember sebesar Rp. 3.589.934.742,00 dengan PPN Sebesar Rp. 358.993.474,20. Dengan demikian total DPP untuk tahun 2014 adalah sebesar Rp. 
46.753.378.648,00 dengan PPN sebesar Rp. 4.675.337.864,80.

b. PPN Masukan / Data pembelian 2015

Tabel 2. Data Pembelian (PM) PT. IKI 2015

\begin{tabular}{llllll}
\hline No & Bulan & Periode & Dpp & Ppn & Jumlah \\
\hline 1 & Januari & 31-Jan-15 & $721.540 .180,00$ & $72.154 .018,00$ & $793.694 .198,00$ \\
\hline 2 & Februari & 28-Feb-15 & $1.961 .832 .328,00$ & $196.183 .232,80$ & $2.158 .015 .560,80$ \\
\hline 3 & Maret & 31-Mar-15 & $476.776 .425,00$ & $47.677 .642,50$ & $524.454 .067,50$ \\
\hline 4 & April & 30-Apr-15 & $1.400 .513 .287,00$ & $140.051 .328,70$ & $1.540 .564 .615,70$ \\
\hline 5 & Mei & 31-Mei-15 & $915.489 .864,00$ & $91.548 .986,40$ & $1.007 .038 .850,40$ \\
\hline 6 & Juni & 30-Jun-15 & $1.605 .552 .732,00$ & $160.555 .273,20$ & $1.766 .108 .005,20$ \\
\hline 7 & Juli & 31-Jul-15 & $621.308 .598,00$ & $62.130 .859,80$ & $683.439 .457,80$ \\
\hline 8 & Agustus & 31-Ag -15 & $519.469 .359,00$ & $51.946 .935,90$ & $571.416 .294,90$ \\
\hline 9 & September & 30-Sep-15 & $570.755 .443,00$ & $57.075 .544,30$ & $627.830 .987,30$ \\
\hline 10 & Oktober & 31-Okt-15 & $570.234 .800,00$ & $57.023 .480,00$ & $627.258 .280,00$ \\
\hline 11 & November & 30-Nov-15 & $602.607 .750,00$ & $60.260 .775,00$ & $662.868 .525,00$ \\
\hline 12 & Desember & 31-Des-15 & $6.962 .024 .032,00$ & $696.202 .403,20$ & $7.658 .226 .435,20$ \\
\hline Jumlah & & $16.928 .104 .798,00$ & $1.692 .810 .479,80$ & $18.620 .915 .277,80$ \\
\hline
\end{tabular}

Sumber : Data PT. Industri kapal Indonesia (diolah)

Berdasarkan tabel 4.3 diatas yang diolah oleh penulis maka diperoleh DPP untuk bulan Januari sebesar Rp. 721.540.180,00 dengan PPN sebesar Rp. 72.154.018,00. Selajutnya DPP untuk Februari Rp. 1.961.832.328,00 dengan PPN sebesar Rp. 196.183.232,80, DPP untuk bulan Maret sebesar Rp. 476.776.425,00 dengan PPN Sebesar Rp. 47.677.642,50, DPP untuk April Rp. 1.400.513.287,00 dengan PPN sebesar Rp. 140.051.328,70, DPP untuk bulan Mei sebesar Rp. 915.489.864,00 dengan PPN Sebesar Rp. 91.548.986,40, DPP untuk bulan Juni sebesar Rp. 1.605.552.732,00 dengan PPN Sebesar Rp. 160.555.273,20, DPP untuk bulan Juli sebesar Rp. 621.308.598,00 dengan PPN Sebesar Rp. 62.130.859,80, DPP untuk bulan Agustus sebesar Rp.

Tabel 3. Data Pembelian (PM) PT. IKI 2016
519.469.359,00 dengan PPN Sebesar Rp. 51.946.935,90, DPP untuk bulan September sebesar Rp. 570.755.443,00 dengan PPN Sebesar Rp. 57.075.544,30, DPP untuk bulan Oktober sebesar Rp. 570.234.800,00 dengan PPN Sebesar Rp. 57.023.480,00, DPP untuk bulan November sebesar Rp. 602.607.750,00 dengan PPN Sebesar Rp. 60.260.775,00 , dan DPP untuk bulan Desember sebesar Rp. 6.962.024.032,00 dengan PPN Sebesar Rp. 696.202.403,20. Dengan demikian total DPP untuk tahun 2015 adalah sebesar Rp. 16.928.104.798,00 dengan PPN sebesar Rp. 1.692.810.479,80.

c. PPN Masukan / Data Pembelian 2016

\begin{tabular}{cllrrr}
\hline NO & BULAN & PERIODE & DPP & PPN & \multicolumn{1}{c}{ JUMLAH } \\
\hline 1 & Januari & 31-Jan-16 & $887.037 .500,00$ & $88.703 .750,00$ & $975.741 .250,00$ \\
\hline 2 & Februari & 28-Feb-16 & $4.866 .900 .637,00$ & $486.690 .063,70$ & $5.353 .590 .700,70$ \\
\hline 3 & Maret & 31-Mar-16 & $3.302 .154 .165,00$ & $330.215 .416,50$ & $3.632 .369 .581,50$ \\
\hline 4 & April & 30-Apr-16 & $3.289 .521 .396,00$ & $328.952 .139,60$ & $3.618 .473 .535,60$ \\
\hline 5 & Mei & 31-Mei-16 & $6.656 .972 .150,00$ & $665.697 .215,00$ & $7.322 .669 .365,00$ \\
\hline 6 & Juni & 30-Jun-16 & $1.324 .378 .621,00$ & $132.437 .862,10$ & $1.456 .816 .483,10$ \\
\hline 7 & Juli & 31-Jul-16 & $688.560 .033,00$ & $68.856 .003,30$ & $757.416 .036,30$ \\
\hline 8 & Agustus & 31-Agt-16 & $2.380 .496 .182,00$ & $238.049 .618,20$ & $2.618 .545 .800,20$ \\
\hline 9 & September & 30-Sep-16 & $6.285 .886 .284,00$ & $628.588 .628,40$ & $6.914 .474 .912,40$ \\
\hline 10 & Oktober & 31-Okt-16 & $1.748 .753 .745,00$ & $174.875 .374,50$ & $1.923 .629 .119,50$ \\
\hline 11 & November & 30-Nov-16 & $3.760 .978 .375,00$ & $376.097 .837,50$ & $4.137 .076 .212,50$ \\
\hline 12 & Desember & 31-Des-16 & $19.974 .950 .414,00$ & $1.997 .495 .041,40$ & $21.972 .445 .455,40$ \\
\hline \multicolumn{2}{c}{ JUMLAH } & $55.166 .589 .502,00$ & $5.516 .658 .950,20$ & $60.683 .248 .452,20$ \\
\hline
\end{tabular}

Sumber : Data PT. Industri kapal Indonesia (diolah) 
Berdasarkan tabel 4.4 diatas yang diolah oleh penulis maka diperoleh DPP untuk bulan Januari sebesar Rp. 887.037.500,00 dengan PPN sebesar Rp. 88.703.750,00 . Selanjutnya DPP untuk Februari Rp. 4.866.900.637,00 dengan PPN sebesar Rp. 486.690.063,70, DPP untuk bulan Maret sebesar Rp. 3.302.154.165,00 dengan PPN Sebesar Rp. 330.215.416,50, DPP untuk April Rp. 3.289.521.396,00 dengan PPN sebesar Rp. 328.952.139,60, DPP untuk bulan Mei sebesar Rp. 6.656.972.150,00 dengan PPN Sebesar Rp. 665.697.215,00 , DPP untuk bulan Juni sebesar Rp. 1.324.378.621,00 dengan PPN Sebesar Rp. 132.437.862,10, DPP untuk bulan Juli sebesar Rp. 688.560.033,00 dengan PPN Sebesar Rp. 68.856.003,30, DPP untuk bulan
Agustus sebesar Rp. 2.380.496.182,00 dengan PPN Sebesar Rp. 238.049.618,20, DPP untuk bulan September sebesar Rp.6.285.886.284,00 dengan PPN Sebesar Rp. 628.588.628,40 , DPP untuk bulan Oktober sebesar Rp. 1.748.753.745,00 dengan PPN Sebesar Rp. 174.875.374,50, DPP untuk bulan November sebesar Rp. 3.760.978.375,00 dengan PPN Sebesar Rp. 376.097.837,50, dan DPP untuk bulan Desember sebesar Rp. 19.974.950.414,00 dengan PPN Sebesar Rp. 1.997.495.041,40. Dengan demikian total DPP untuk tahun 2016 adalah sebesar Rp. 55.166.589.502,00 dengan PPN sebesar Rp. $5.516 .658 .950,20$

d. PPN Masukan / data Pembelian 2017

Tabel 4. Data Pembelian (PM) PT. IKI 2017

\begin{tabular}{rllrrr}
\hline No & Bulan & Periode & \multicolumn{1}{c}{ Dpp } & \multicolumn{1}{c}{ Ppn } & \multicolumn{1}{c}{ Jumlah } \\
\hline 1 & Januari & 31-Jan-17 & $3.107 .942 .543,00$ & $310.794 .254,30$ & $3.418 .736 .797,30$ \\
\hline 2 & Februari & 28-Feb-17 & $10.520 .425 .460,00$ & $1.052 .042 .546,00$ & $11.572 .468 .006,00$ \\
\hline 3 & Maret & 31-Mar-17 & $8.870 .810 .483,00$ & $887.081 .048,30$ & $9.757 .891 .531,30$ \\
\hline 4 & April & 30-Apr-17 & $370.277 .385,00$ & $37.027 .738,50$ & $407.305 .123,50$ \\
\hline 5 & Mei & 31-Mei-17 & $13.099 .665 .780,00$ & $1.309 .966 .578,00$ & $14.409 .632 .358,00$ \\
\hline 6 & Juni & 30-Jun-17 & $603.531 .915,00$ & $60.353 .191,50$ & $663.885 .106,50$ \\
\hline 7 & Juli & 31-Jul-17 & $12.203 .200 .325,00$ & $1.220 .320 .032,50$ & $13.423 .520 .357,50$ \\
\hline 8 & Agustus & 31-Agt -17 & $1.715 .097 .394,00$ & $171.509 .739,40$ & $1.886 .607 .133,40$ \\
\hline 9 & September & 30-Sep-17 & $11.487 .757 .642,00$ & $1.148 .775 .764,20$ & $12.636 .533 .406,20$ \\
\hline 10 & Oktober & 31 -Okt-17 & $7.880 .428 .832,00$ & $788.042 .883,20$ & $8.668 .471 .715,20$ \\
\hline 11 & November & 30-Nov-17 & $22.388 .580 .343,00$ & $2.238 .858 .034,30$ & $24.627 .438 .377,30$ \\
\hline 12 & Desember & 31-Des-17 & $4.010 .070 .340,00$ & $401.007 .034,00$ & $4.411 .077 .374,00$ \\
\hline \multicolumn{7}{c}{ Jumlah } & $96.257 .788 .442,00$ & $9.625 .778 .844,20$ & $105.883 .567 .286,20$ \\
\hline Sum
\end{tabular}

Sumber : Data PT. Industri kapal Indonesia (diolah)

Berdasarkan tabel 4.5 diatas yang diolah oleh penulis maka diperoleh DPP untuk bulan Januari sebesar Rp. 3.107.942.543,00 dengan PPN sebesar Rp. 310.794.254,30. Selajutnya DPP untuk Februari Rp. 10.520.425.460,00 dengan PPN sebesar Rp. 1.052.042.546,00, DPP untuk bulan Maret sebesar Rp. 8.870.810.483,00 dengan PPN Sebesar Rp. 887.081.048,30, DPP untuk April Rp. 370.277.385,00 dengan PPN sebesar Rp. 37.027.738,50, DPP untuk bulan Mei sebesar Rp. 13.099.665.780,00 dengan PPN Sebesar Rp. 1.309.966.578,00, DPP untuk bulan Juni sebesar Rp. 603.531.915,00 dengan PPN Sebesar Rp. 60.353.191,50, DPP untuk bulan Juli sebesar Rp. 12.203.200.325,00 dengan PPN Sebesar Rp. 1.220.320.032,50, DPP untuk bulan Agustus sebesar Rp. 1.715.097.394,00 dengan PPN Sebesar Rp. 171.509.739,40, DPP untuk bulan September sebesar Rp 11.487.757.642,00 dengan PPN
Sebesar Rp. 1.148.775.764,20, DPP untuk bulan Oktober sebesar Rp. 7.880.428.832,00 dengan PPN Sebesar Rp. 788.042.883,20, DPP untuk bulan November sebesar Rp. 22.388.580.343,00 dengan PPN Sebesar Rp. 2.238.858.034,30 , dan DPP untuk bulan Desember sebesar Rp. 4.010.070.340,00 dengan PPN Sebesar Rp. 401.007.034,00. Dengan demikian total DPP untuk tahun 2016 adalah sebesar Rp. 96.257.788.442,00 dengan PPN sebesar Rp. 9.625.778.844,20.

\section{Perhitungan PPN Keluaran}

Pajak keluaran dikenakan ketika pengusaha kena pajak melakukan penjualan terhadap barang kena pajak atau jasa kena pajak. PT. Industri Kapal Indonesia telah melakukan penjualan selama lima tahun berturut-turut mulai dari tahun 2013 sampai 2015. Berikut disajikan data PPN Keluaran yang dilakukan oleh PT. IKI : 
a. PPN Keluaran / Data Pembelian 2013

Tabel 5. Data Penjualan (PK) 2013

\begin{tabular}{cllrrr}
\hline No & Bulan & Periode & \multicolumn{1}{c}{ Dpp } & \multicolumn{1}{c}{ Ppn } & \multicolumn{1}{c}{ Jumlah } \\
\hline 1 & Januari & 31-Jan-13 & $1.680 .650 .150,00$ & $168.065 .015,00$ & $1.848 .715 .165,00$ \\
\hline 2 & Februari & 28-Feb-13 & $1.424 .430 .700,00$ & $142.443 .070,00$ & $1.566 .873 .770,00$ \\
\hline 3 & Maret & 31-Mar-13 & $610.000 .000,00$ & $61.000 .000,00$ & $671.000 .000,00$ \\
\hline 4 & April & 30-Apr-13 & $2.905 .356 .755,00$ & $290.535 .675,50$ & $3.195 .892 .430,50$ \\
\hline 5 & Mei & 31-Mei-13 & $1.728 .317 .700,00$ & $172.831 .770,00$ & $1.901 .149 .470,00$ \\
\hline 6 & Juni & 30-Jun-13 & $104.621 .010,00$ & $10.462 .101,00$ & $115.083 .111,00$ \\
\hline 7 & Juli & 31-Jul-13 & $1.468 .211 .837,00$ & $146.821 .183,70$ & $1.615 .033 .020,70$ \\
\hline 8 & Agustus & 31-Agt-13 & $1.485 .991 .115,00$ & $148.599 .111,50$ & $1.634 .590 .226,50$ \\
\hline 9 & September & 30-Sep-13 & $691.863 .910,00$ & $69.186 .391,00$ & $761.050 .301,00$ \\
\hline 10 & Oktober & 31-Okt-13 & $572.947 .153,00$ & $57.294 .715,30$ & $630.241 .868,30$ \\
\hline 11 & November & 30-Nov-13 & $2.743 .522 .062,00$ & $274.352 .206,20$ & $3.017 .874 .268,20$ \\
\hline 12 & Desember & 31-Des-13 & $13.607 .908 .975,00$ & $1.360 .790 .897,50$ & $14.968 .699 .872,50$ \\
\hline \multicolumn{7}{r}{ JUMLAH } & $29.023 .821 .367,00$ & $2.902 .382 .136,70$ & $31.926 .203 .503,70$ \\
\hline
\end{tabular}

Sumber : Data PT. Industri kapal Indonesia 2018 (diolah)

Berdasarkan tabel 5 diatas yang diolah oleh penulis maka diperoleh DPP untuk bulan Januari sebesar Rp. 1.680.650.150,00 dengan PPN sebesarRp.168.065.015,00. Selanjutnya DPP untuk Februari Rp. 1.424.430.700,00 dengan PPN sebesar Rp. 142.443.070,00, DPP untuk bulan Maret sebesar Rp. 610.000.000,00 dengan PPN Sebesar Rp. 61.000.000,00, DPP untuk April Rp. 2.905.356.755,00 dengan PPN sebesar Rp. 290.535.675,50 , DPP untuk bulan Mei sebesar Rp.1.728.317.700,00 dengan PPN Sebesar Rp. 172.831.770,00, DPP untuk bulan Juni sebesar Rp.104.621.010,00 dengan PPN Sebesar Rp. 10.462.101,00, DPP untuk bulan Juli sebesar Rp. 1.468.211.837,00 denganPPN Sebesar Rp.146.821.183,70, DPP untuk bulan Agustus sebesar
Rp.1.485.991.115,00 dengan PPN Sebesar Rp. 148.599.111,50, DPP untuk bulan September sebesar Rp. 691.863.910,00 dengan PPN Sebesar Rp. 69.186.391,00, DPP untuk bulan Oktober sebesar Rp. 572.947.153,00 dengan PPN Sebesar Rp. 57.294.715,30 , DPP untuk bulan November sebesar Rp. 2.743.522.062,00 dengan PPN Sebesar Rp. 274.352.206,20, dan DPP untuk bulan Desember sebesar Rp. 13.607.908.975,00 dengan PPN Sebesar Rp. 1.360.790.897,50. Dengan demikian total DPP untuk tahun 2016 adalah sebesar Rp.29.023.821.367,00 dengan PPN sebesar Rp. 2.902.382.136,70.

b. PPN Keluaran / Data Penjualan 2014

Tabel 6. Data Penjualan (PK) 2014

\begin{tabular}{cllrrr}
\hline No & Bulan & Periode & DPP & PPN & \multicolumn{1}{c}{ Jumlah } \\
\hline 1 & Januari & 31-Jan-14 & $122.293 .550,00$ & $12.229 .355,00$ & $134.522 .905,00$ \\
\hline 2 & Februari & 28-Feb-14 & $1.890 .171 .458,00$ & $189.017 .145,80$ & $2.079 .188 .603,80$ \\
\hline 3 & Maret & 31-Mar-14 & $1.273 .596 .299,00$ & $127.359 .629,90$ & $1.400 .955 .928,90$ \\
\hline 4 & April & 30-Apr-14 & $2.008 .550 .039,00$ & $200.855 .003,90$ & $2.209 .405 .042,90$ \\
\hline 5 & Mei & 31-Mei-14 & $4.157 .486 .309,00$ & $415.748 .630,90$ & $4.573 .234 .939,90$ \\
\hline 6 & Juni & 30-Jun-14 & $2.126 .078 .166,00$ & $212.607 .816,60$ & $2.338 .685 .982,60$ \\
\hline 7 & Juli & 31-Jul-14 & $728.904 .482,00$ & $72.890 .448,20$ & $801.794 .930,20$ \\
\hline 8 & Agustus & 31-Agt -14 & $2.434 .659 .794,00$ & $243.465 .979,40$ & $2.678 .125 .773,40$ \\
\hline 9 & September & 30-Sep-14 & $3.339 .299 .122,00$ & $333.929 .912,20$ & $3.673 .229 .034,20$ \\
\hline 10 & Oktober & 31-Okt-14 & $2.573 .437 .590,00$ & $257.343 .759,00$ & $2.830 .781 .349,00$ \\
\hline 11 & November & 30-Nov-14 & $10.013 .120 .867,00$ & $1.001 .312 .086,70$ & $11.014 .432 .953,70$ \\
\hline 12 & Desember & 31-Des-14 & $9.217 .509 .636,00$ & $921.750 .963,60$ & $10.139 .260 .599,60$ \\
\hline \multicolumn{2}{r}{ JUMLAH } & $39.885 .107 .312,00$ & $3.988 .510 .731,20$ & $43.873 .618 .043,20$ \\
\hline
\end{tabular}

Sumber : Data PT. Industri kapal Indonesia 2018 (diolah)

Berdasarkan tabel 6 diatas yang diolah oleh penulis maka diperoleh DPP untuk bulan Januari sebesar Rp. 122.293.550,00 dengan
PPN sebesarRp. 12.229.355,00. Selanjutnya DPP untuk Februari Rp. 1.890.171.458,00 dengan PPN sebesar Rp. 189.017.145,80, DPP 
untuk bulan Maret sebesar Rp. 1.273.596.299,00 dengan PPN Sebesar Rp. 127.359.629,90, DPP untuk April Rp. 2.008.550.039,00 dengan PPN sebesar Rp. 200.855.003,90, DPP untuk bulan Mei sebesar Rp. 4.157.486.309,00 dengan PPN Sebesar Rp. 415.748.630,90, DPP untuk bulan Juni sebesar Rp.2.126.078.166,00 dengan PPN Sebesar Rp. 212.607.816,60, DPP untuk bulan Juli sebesar Rp.728.904.482,00 dengan PPN Sebesar Rp. 72.890.448,20, DPP untuk bulan Agustus sebesar Rp.2.434.659.794,00 dengan PPN Sebesar Rp.243.465.979,40DPP u ntuk bulan September sebesar Rp.3.339.299.122,00 dengan PPN Sebesar Rp. 333.929.912,20, DPP untuk bulan Oktober sebesar Rp. 2.573.437.590,00 dengan PPN Sebesar Rp. 257.343.759,00, DPP untuk bulan November sebesar Rp.10.013.120.867,00 dengan PPN Sebesar Rp.1.001.312.086,70, dan DPP untuk bulan Desember sebesar Rp. 9.217.509.636,00 dengan PPN Sebesar Rp. 921.750.963,60. Dengan demikian total DPP untuk tahun 2014 adalah sebesar Rp.39.885.107.312,00 dengan PPN sebesar Rp. 3.988.510.731,20.

c. PPN Keluaran / Data Penjualan 2015

Tabel 7. Data Penjualan (PK) 2015

\begin{tabular}{rllrrr}
\hline No & Bulan & Periode & DPP & PPN & \multicolumn{1}{c}{ Jumlah } \\
\hline 1 & Januari & 31-Jan-15 & $660.542 .000,00$ & $66.054 .200,00$ & $726.596 .200,00$ \\
\hline 2 & Februari & 28-Feb-15 & $3.900 .746 .149,00$ & $390.074 .614,90$ & $4.290 .820 .763,90$ \\
\hline 3 & Maret & 31-Mar-15 & $2.225 .537 .243,00$ & $222.553 .724,30$ & $2.448 .090 .967,30$ \\
\hline 4 & April & 30-Apr-15 & $2.700 .930 .365,00$ & $270.093 .036,50$ & $2.971 .023 .401,50$ \\
\hline 5 & Mei & 31-Mei-15 & $3.381 .907 .719,00$ & $338.190 .771,90$ & $3.720 .098 .490,90$ \\
\hline 6 & Juni & 30-Jun-15 & $9.175 .136 .087,00$ & $917.513 .608,70$ & $10.092 .649 .695,70$ \\
\hline 7 & Juli & 31-Jul-15 & $2.567 .361 .026,00$ & $256.736 .102,60$ & $2.824 .097 .128,60$ \\
\hline 8 & Agustus & 31-Agt-15 & $9.175 .136 .087,00$ & $917.513 .608,70$ & $10.092 .649 .695,70$ \\
\hline 9 & September & 30-Sep-15 & $3.210 .192 .849,00$ & $321.019 .284,90$ & $3.531 .212 .133,90$ \\
\hline 10 & Oktober & 31-Okt-15 & $8.094 .164 .735,00$ & $809.416 .473,50$ & $8.903 .581 .208,50$ \\
\hline 11 & November & 30-Nov-15 & $5.071 .799 .505,00$ & $507.179 .950,50$ & $5.578 .979 .455,50$ \\
\hline 12 & Desember & 31-Des-15 & $54.673 .406 .122,00$ & $5.467 .340 .612,20$ & $60.140 .746 .734,20$ \\
\hline \multicolumn{7}{c}{ JUMLAH } & $104.836 .859 .887,00$ & $10.483 .685 .988,70$ & $115.320 .545 .875,70$ \\
\hline
\end{tabular}

Sumber : Data PT. Industri kapal Indonesia 2018 (diolah)

Berdasarkan tabel 7 diatas yang diolah oleh penulis maka diperoleh DPP untuk bulan Januari sebesar Rp.660.542.000,00 dengan PPN sebesarRp. 66.054.200,00. Selanjutnya DPP untuk Februari Rp. 3.900.746.149,00 dengan PPN sebesar Rp. 390.074.614,90, DPP untuk bulan Maret sebesar Rp.2.225.537.243,00 dengan PPN Sebesar Rp.222.553.724,30, DPP untuk April Rp.2.700.930.365,00 dengan PPN sebesar Rp.270.093.036,50, DPP untuk bulan Mei sebesar Rp.3.381.907.719,00 dengan PPN Sebesar Rp.338.190.771,90, DPP untuk bulan Juni sebesar Rp.9.175.136.087,00dengan PPN Sebesar Rp. 917.513.608,70, DPP untuk bulan Juli sebesar Rp.2.567.361.026,00 denganPPN Sebesar Rp.256.736.102,60, DPP untuk bulan Agustussebesar Rp. 9.175.136.087,00 dengan
PPN Sebesar Rp.917.513.608,70DPP untuk bulan September sebesar Rp. 3.210.192.849,00 dengan PPN Sebesar Rp.321.019.284,90, DPP untuk bulan Oktober sebesar Rp.8.094.164.735,00dengan PPN Sebesar Rp. 809.416.473,50, DPP untuk bulan November sebesar Rp.5.071.799.505,00 dengan PPN Sebesar Rp. 507.179.950,50 , dan DPP untuk bulan Desember sebesar Rp. 54.673.406.122,00 dengan PPN Sebesar Rp. 5.467.340.612,20. Dengan demikian total DPP untuk tahun 2015 adalah sebesar Rp.104.836.859.887,00 dengan PPN sebesar Rp. 10.483.685.988,70.

d. PPN Keluaran / Data Penjualan 2016

Tabel 8. Data Penjualan (PK) 2016

\begin{tabular}{cllccl}
\hline No & Bulan & Periode & Dpp & Ppn & Jumlah \\
\hline 1 & Januari & 31-Jan-16 & $4.674 .753 .547,00$ & $467.475 .354,70$ & $5.142 .228 .901,70$ \\
\hline 2 & Februari & 28-Feb-16 & $1.658 .025 .850,00$ & $165.802 .585,00$ & $1.823 .828 .435,00$ \\
\hline 3 & Maret & 31-Mar-16 & $3.998 .645 .383,00$ & $399.864 .538,30$ & $4.398 .509 .921,30$ \\
\hline
\end{tabular}




\begin{tabular}{|c|c|c|c|c|c|}
\hline 4 & April & 30-Apr-16 & $4.914 .684 .118,00$ & $491.468 .411,80$ & $5.406 .152 .529,80$ \\
\hline 5 & Mei & 31-Mei-16 & $3.260 .054 .732,00$ & $326.005 .473,20$ & $3.586 .060 .205,20$ \\
\hline 6 & Juni & 30-Jun-16 & $5.309 .810 .637,00$ & $530.981 .063,70$ & $5.840 .791 .700,70$ \\
\hline 7 & Juli & 31- Jul-16 & $4.705 .228 .682,00$ & $470.522 .868,20$ & $5.175 .751 .550,20$ \\
\hline 8 & Agustus & 31 -Agt-16 & $3.667 .592 .213,00$ & $366.759 .221,30$ & $4.034 .351 .434,30$ \\
\hline 9 & September & 30-Sep-16 & $32.643 .797 .491,00$ & $3.264 .379 .749,10$ & $35.908 .177 .240,10$ \\
\hline 10 & Oktober & $31-$ Okt-16 & $3.814 .065 .646,00$ & $381.406 .564,60$ & $4.195 .472 .210,60$ \\
\hline 11 & November & $30-N o v-16$ & $36.118 .501 .550,00$ & $3.611 .850 .155,00$ & $39.730 .351 .705,00$ \\
\hline 12 & Desember & 31-Des-16 & $20.290 .771 .934,00$ & $2.029 .077 .193,40$ & $22.319 .849 .127,40$ \\
\hline \multicolumn{3}{|c|}{ JUMLAH } & $125.055 .931 .783,00$ & $12.505 .593 .178,30$ & $137.561 .524 .961,30$ \\
\hline
\end{tabular}

Sumber : Data PT. Industri kapal Indonesia 2018 (diolah)

Berdasarkan tabel 4.9diatas yang diolah oleh penulis maka diperoleh DPP untuk bulan Januari sebesar Rp. 4.674.753.547,00 dengan PPN sebesarRp. 467.475.354,70. Selanjutnya DPP untuk Februari Rp.1.658.025.850,00 dengan PPN sebesar Rp. 165.802.585,00DPP untuk bulan Maret sebesar Rp.3.998.645.383,00 dengan PPN Sebesar Rp. 399.864.538,30, DPP untuk April Rp. 4.914.684.118,00 dengan PPN sebesar Rp. 491.468.411,80 , DPP untuk bulan Mei sebesar Rp. 3.260.054.732,00 dengan PPN Sebesar Rp. 326.005.473,20, DPP untuk bulan Juni sebesar Rp. 5.309.810.637,00 dengan PPN Sebesar Rp. 530.981.063,70 ,DPP untuk bulan Juli sebesar Rp.4.705.228.682,00 dengan PPN Sebesar Rp.470.522.868,20, DPP untuk bulan Agustus sebesar
Rp.3.667.592.213,00 dengan PPN Sebesar Rp.366.759.221,30 DPP untuk bulan September sebesar Rp. 32.643.797.491,00 dengan PPN Sebesar Rp.3.264.379.749,10, DPP untuk bulan Oktober sebesar Rp. 3.814.065.646,00 dengan PPN Sebesar Rp. 381.406.564,60, DPP untuk bulan November sebesar Rp36.118.501.550,00 dengan PPN Sebesar Rp. 3.611.850.155,00, dan DPP untuk bulan Desember sebesar Rp. 20.290.771.934,00 dengan PPN Sebesar Rp.2.029.077.193,40. Dengan demikian total DPP untuk tahun 2015 adalah sebesar Rp.125.055.931.783,00 dengan PPN sebesar Rp. 12.505.593.178,30.

e. PPN Keluar/Data Penjualan 2017

Tabel 9. Data Penjualan (PK) 2017

\begin{tabular}{clrrrr}
\hline No & Bulan & Periode & \multicolumn{1}{c}{ Dpp } & \multicolumn{1}{c}{ Ppn } & \multicolumn{1}{c}{ Jumlah } \\
\hline 1 & Januari & 31-Jan-17 & $5.365 .991 .379,00$ & $536.599 .137,90$ & $5.902 .590 .516,90$ \\
\hline 2 & Februari & 28-Feb-17 & $5.904 .282 .230,00$ & $590.428 .223,00$ & $6.494 .710 .453,00$ \\
\hline 3 & Maret & 31-Mar-17 & $29.197 .559 .846,00$ & $2.919 .755 .984,60$ & $32.117 .315 .830,60$ \\
\hline 4 & April & 30-Apr-17 & $3.933 .698 .835,00$ & $393.369 .883,50$ & $4.327 .068 .718,50$ \\
\hline 5 & Mei & 31-Mei-17 & $6.237 .935 .929,00$ & $623.793 .592,90$ & $6.861 .729 .521,90$ \\
\hline 6 & Juni & 30-Jun-17 & $3.806 .218 .053,00$ & $380.621 .805,30$ & $4.186 .839 .858,30$ \\
\hline 7 & Juli & 31-Jul -17 & $2.305 .921 .446,00$ & $230.592 .144,60$ & $2.536 .513 .590,60$ \\
\hline 8 & Agustus & 31-Agt-17 & $32.895 .500 .824,00$ & $3.289 .550 .082,40$ & $36.185 .050 .906,40$ \\
\hline 9 & September & 30-Sep-17 & $2.893 .630 .788,00$ & $289.363 .078,80$ & $3.182 .993 .866,80$ \\
\hline 10 & Oktober & 31 -Okt-17 & $36.977 .193 .311,00$ & $3.697 .719 .331,10$ & $40.674 .912 .642,10$ \\
\hline 11 & November & 30-Nov-17 & $7.481 .817 .170,00$ & $748.181 .717,00$ & $8.229 .998 .887,00$ \\
\hline 12 & Desember & 31-Des-17 & $44.618 .491 .433,00$ & $4.461 .849 .143,30$ & $49.080 .340 .576,30$ \\
\hline \multicolumn{7}{c}{ JUMLAH } & $181.618 .241 .244,00$ & $18.161 .824 .124,40$ & $199.780 .065 .368,40$ \\
\hline Sul
\end{tabular}

Sumber : Data PT. Industri kapal Indonesia 2018 (diolah)

Berdasarkan tabel 4.10 diatas yang diolah oleh penulis maka diperoleh DPP untuk bulan Januari sebesar Rp. 5.365.991.379,00 dengan PPN sebesarRp. 536.599.137,90. Selanjutnya DPP untuk Februari Rp. 5.904.282.230,00 dengan PPN sebesarRp.590.428.223,00 DPP untuk bulan Maret sebesar Rp.29.197.559.846,00 dengan PPN Sebesar Rp. 2.919.755.984,60, DPP untuk April
Rp. 3.933.698.835,00 dengan PPN sebesar Rp. 393.369.883,50, DPP untuk bulan Mei sebesar Rp. 6.237.935.929,00 dengan PPN Sebesar R623.793.592,90, DPP untuk bulan Juni sebesar Rp. 3.806.218.053,00 dengan PPN Sebesar Rp. 380.621.805,30, DPP untuk bulan Juli sebesar Rp. 2.305.921.446,00 dengan PPN Sebesar Rp.230.592.144,60, DPP untuk bulan Agustus sebesar 
Rp.32.895.500.824,00 dengan PPN Sebesar Rp. 3.289.550.082,40 , DPP untuk bulan September sebesar Rp. 2.893.630.788,00 dengan PPN Sebesar Rp. 289.363.078,80, DPP untuk bulan Oktober sebesar Rp.36.977.193.311,00 dengan PPN Sebesar Rp.3.697.719.331,10, DPP untuk bulan November sebesar Rp.7.481.817.170,00 dengan PPN Sebesar Rp.748.181.717,00 , dan DPP untuk bulan Desember sebesar Rp. 44.618.491.433,00 dengan PPN Sebesar Rp 4.461.849.143,30. Dengan demikian total DPP untuk tahun 2017 adalah sebesar Rp.181.618.241.244,00 dengan PPN sebesar Rp. 18.161.824.124,40.

Tabel 10. Data perbandingan PM dan PK

\section{Perbandingan Data PPN Masukan dan PPN Keluaran PT. Industri Kapal Indonesia}

a. Perbandingan Data PPN Masukan dan PPN Keluaran 2013

\begin{tabular}{|c|c|c|c|c|c|}
\hline BULAN & PERIODE & PM & $\mathbf{P K}$ & JUMLAH & $\begin{array}{c}\text { KETERANGA } \\
\mathbf{N}\end{array}$ \\
\hline Januari & 31-Jan-13 & $65.006 .385,00$ & $168.065 .015,00$ & - 103.058.630,00 & Kurang bayar \\
\hline Februari & $28-F e b-13$ & $93.182 .839,80$ & $142.443 .070,00$ & - $49.260 .230,20$ & Kurang bayar \\
\hline Maret & 31-Mar-13 & $9.412 .927,30$ & $61.000 .000,00$ & - $51.587 .072,70$ & Kurang bayar \\
\hline April & 30-Apr-13 & $3.584 .800,00$ & $290.535 .675,50$ & $-286.950 .875,50$ & Kurang bayar \\
\hline Mei & 31-Mei-13 & $46.399 .150,00$ & $172.831 .770,00$ & $-126.432 .620,00$ & Kurang bayar \\
\hline Juni & 30-Jun-13 & $484.000,00$ & $10.462 .101,00$ & $\begin{array}{l}-9.978 .101,00 \\
\end{array}$ & Kurang bayar \\
\hline Juli & 31-Jul- 13 & $4.932 .230,00$ & $146.821 .183,70$ & $-141.888 .953,70$ & Kurang bayar \\
\hline Agustus & 31-Agt- 13 & $4.081 .000,00$ & $148.599 .111,50$ & $-144.518 .111,50$ & Kurang bayar \\
\hline September & 30-Sep-13 & $5.234 .510,00$ & $69.186 .391,00$ & $\begin{array}{l}-63.951 .881,00 \\
\end{array}$ & Kurang bayar \\
\hline Oktober & $31-$ Okt-13 & $27.032 .880,00$ & $57.294 .715,30$ & $-\quad 30.261 .835,30$ & Kurang bayar \\
\hline November & 30-Nov-13 & $73.958 .895,00$ & $274.352 .206,20$ & - 200.393.311,20 & Kurang bayar \\
\hline Desember & 31-Des-13 & $1.207 .692 .486,80$ & $1.360 .790 .897,50$ & $-153.098 .410,70$ & Kurang bayar \\
\hline \multicolumn{2}{|c|}{ JUMLAH } & $1.541 .002 .103,90$ & $2.902 .382 .136,70$ & $-1.361 .380 .032,80$ & \\
\hline
\end{tabular}

Sumber : Data PT. Industri kapal Indonesia 2018 (diolah)

Berdasarakan tabel 10 diatas untuk bulan Januari sampai bulan Desember 2013 PPN Keluaran lebih besar daripada PPN Masukan sehingga semuanya kurang bayar. b. Perbandingan Data PPN Masukan dan PPN Keluaran 2014

Tabel 11. Data perbandingan PM dan PK 2014

\begin{tabular}{|c|c|c|c|c|c|}
\hline Bulan & Periode & PM & PK & Jumlah & Keterangan \\
\hline Januari & 31-Jan-14 & $28.207 .950,00$ & $12.229 .355,00$ & $15.978 .595,00$ & Lebih bayar \\
\hline Februari & 28-Feb-14 & $178.784 .110,00$ & $189.017 .145,80$ & $-\quad 10.233 .035,80$ & kurang bayar \\
\hline Maret & 31-Mar-14 & $80.644 .590,80$ & $127.359 .629,90$ & - $46.715 .039,10$ & kurang bayar \\
\hline April & 30-Apr-14 & $84.650 .251,20$ & $200.855 .003,90$ & $-116.204 .752,70$ & kurang bayar \\
\hline Mei & 31-Mei-14 & $173.684 .245,00$ & $415.748 .630,90$ & - $242.064 .385,90$ & kurang bayar \\
\hline Juni & 30-Jun-14 & $111.151 .565,00$ & $212.607 .816,60$ & $-101.456 .251,60$ & kurang bayar \\
\hline Juli & 31-Ju 1- 14 & $1.598 .471 .520,50$ & $72.890 .448,20$ & $1.525 .581 .072,30$ & Lebih bayar \\
\hline Agustus & 31-Agt -14 & $243.465 .979,40$ & $794.448 .711,10$ & $-550.982 .731,70$ & kurang bayar \\
\hline September & 30-Sep-14 & $180.754 .015,00$ & $333.929 .912,20$ & $-153.175 .897,20$ & kurang bayar \\
\hline Oktober & $31-$ Okt-14 & $257.343 .759,00$ & $838.008 .981,10$ & $-580.665 .222,10$ & kurang bayar \\
\hline November & 30-Nov-14 & $247.538 .450,90$ & $1.001 .312 .086,70$ & $-753.773 .635,80$ & kurang bayar \\
\hline Desember & 31-Des-14 & $358.993 .474,20$ & $921.750 .963,60$ & - $562.757 .489,40$ & kurang bayar \\
\hline \multicolumn{2}{|c|}{ JUMLAH } & $3.543 .689 .911,00$ & $5.120 .158 .685,00$ & $-1.576 .468 .774,00$ & \\
\hline
\end{tabular}

Sumber : Data PT. Industri kapal Indonesia 2018 (diolah) 
Berdasarkan tabel 11 diatas untuk bulan Januari Pajak Masukan lebih besar sehingga lebih bayar, selanjutnya untuk bulan Februari sampai Juni Pajak keluaran lebih besar sehingga kurang bayar, untuk bulan Juli Pajak Masukan lebih besar sehingga lebih bayar, dan untuk bulan Agustus sampaiDesember Pajak keluaran lebih besar sehingga semua kurang bayar.

\section{Pembahasan}

Berdasarkan hasil analisis yang dilakukan penulis tentang perhitungan dan pelaporan PPN pada PT. Industri Kapal Indonesia, diperoleh hasil Perhitungan dan pelaporan pajak pertambahan nilai di PT. Industri Kapal Indonesia Hasil penelitian untuk hipotesis pertama bahwa perhitungan dan pelaporan pajak pertambahan nilai yang dilakukan oleh PT. IKI sudah baik, dimana dapat dilihat pada hasil penelitian diatas, mulai dari perhitungan PPN Masukan dan PPN keluaran, perbandingan antara PPN Masukan dan PPN keluaran sudah dihitung dengan baik, serta Pelaporan SPT Masa PPN mulai dari tahun 2013 sampai 2017 sudah dilaporkan dengan baik pula, dikarenakan karyawan yang bekerja di bagian perpajakan sudah berkompeten di bidang perpajakan dan pada setiap akhir bulan PT. IKI membuat closing journal untuk menutup perkiraan PPn baik untuk PPn masukan maupun untuk PPn keluaran.

Hasil penelitian ini sejalan dengan penelitian yang dilakukan oleh Sepang, Dkk (2014) pada PT. Simple Jaya Manado, bahwa perusahaan telah melakukan perhitungan dan pelaporan ppn dengan baik.

Perhitungan dan pelaporan pajak pertambahan nilai di PT. Industri Kapal Indonesia sudah sesuai Undang-undang PPN No. 42 tahun 2009 Hasil penelitian untuk hipotesis kedua bahwa dalam perhitungan PPN Masa PT. IKI yang terutang telah dilakukan dengan benar sesuai pasal 7 Undang-undang No 42 tahun 2009 yaitu PPN dihitung dengan mengalikan harga barang dengan tarif pajak sebesar $10 \%$. Pada analisis pajak kurang bayar dan lebih bayar dilakukan dengan membandingkan antara pajak masukan dengan pajak keluaran, dimana apabila PPN Keluaran lebih besar dari PPN Masukan maka terjadi pajak kurang bayar, seperti perbandingan antarapajak masukan dan pajak keluaran pada bulan januari sampai desember tahun 2013 telah terjadi kurang bayar. Sebaliknya apabila PPN masukan lebih besar dari PPN keluaran maka terjadi pajak lebih bayar dan akan di kompensasikan ke bulan berikutnya, seperti pada bulan januari 2015 terjadi lebih bayar sebesar Rp.6.099.818,00 yang di kompensasikan ke bulan februari.

Dalam hal pelaporan SPT Masa PPN pada PT. IKI telah dilakukan sesuai dengan UU No 42 Tahun 2009, hal ini terbukti seperti yang dilihat pada hasil analisis data terkait dengan waktu pelaporan SPT Masa PPN terhitung dari bulan Januari 2013 sampai Desember 2017 dilaporkan rata-rata sebelum tanggal pelaporan atau sebelum batas waktu penyampaian SPT Masa PPN untuk setiap bulanyaitu paling lambat dilaporkan 15 hari setelah tanggal akhir bulan.Hal ini dikarenakan bagian pajak selalu melakukan pendataan terkait dengan pelaporan SPT Masa PPN. Hasil penelitian ini sejalan dengan penelitian yang dilakukan oleh Manarisip (2013) pada PT. Swa Karya Muda Balikpapan bahwa Perhitungan dan Pelaporan PPN sudah dilakukan dengan benar dan sesuai dengan ketentuan perpajakan yang berlaku yaitu Undang-undang PPN No. 42 tahun 2009.

\section{KESIMPULAN}

a. Kesimpulan

Berdasarkan hasil penelitian dan pembahasan diatas dapat ditarik kesimpulan bahwa :

1) Perhitungan dan Pelaporan Pajak Pertambahan Nilai yang dilakukan oleh PT. Industri Kapal Indonesia sudah baik dikarenakan karyawan yang bekerja di bagian perpajakan sudah berkompeten di bidang perpajakan.

2) Perhitungan dan Pelaporan Pajak Pertambahan Nilai pada PT. Industri Kapal Indonesia juga telah sesuai dengan Undang-undang PPN No. 42 tahun 2009

b. Saran

Adapun saran yang dapat diberikan peneliti yaitu:

1) PT. Industri Kapal Indonesia akan lebih baik jika dalam pembuatan SPT Masa PPN disiapkan lebih awal jauh sebelum tanggal jatuh tempoh pelaporan. Sehingga suatu saat pada tanggal jatuh tempo merupakan 
hari libur atau hari besar, maka PT. IKI bisa lebih awal melaporkanya.

2) Diharapkan PT.Industri Kapal Indonesia dapat mempertahankan dan meningkatkan lagi tata cara perhitungan dan pelaporan PPN nya untuk menghindari kesalahan yang dapat merugikan perusahaan

\section{REFERENSI}

Darmayanti, N. 2012. Analisis perhitungan pajak pertambahan nilai pada $\mathrm{CV}$. Sarana Teknik kontrol Surabaya, (Online), Vol. 1, No. 3 (https://media.neliti.com/media/publicat ions/111393-ID-none.pdf, diakses 23 januari 2018)

Diana. 2013. Konsep Dasar Perapajakan. Bandung: PT.Refika Aditama

Djuanda,G dan Lubis, I. 2011. Pelaporan Pajak Pertambahan Nilai dan Pajak Penjualan Atas Barang Mewah. Jakarta : PT. Gramedia PustakaUtama.

Irwan. Michell. 2017. Manajemen Perpajakan. Jakarta : Mitra Wacana Media.

Manarisip,JC. 2013. Evaluasi perhitungan, pencatatan, pelaporan PPN PT.Swakarya Muda Balikpapan, $(\mathrm{O}$ nline),Vol.1, No.3, ( https://ejournal.uns rat.ac.id/index.php/emba/article/view/18 67, diakses 23 januari 2018)

Mardiasmo. 2011. Perpajakan. edisi revisi 2011.Yogyakarta: Andi.

Putra, M. 2016. Analisis perhitungan dan pelaporan Pajak pertambahan nilai pada PT.Fajar Mas Karyatama, (Online), Vol. 4, No. 005, (https:// economics bosowa.unibos.id/index.php/eb/article/d ownload/55/51, diakses 23 januari 2018)

Rendy Daryl Pandelak. 2013. Analisis perhitu ngan dan pelaporan ppn Pada PT. Mabe r Teknindo, (Online), Vol.1, No.3, (http s://ejournal.unsrat.ac.id/index.php/emba /article/view/1952, diakses 23 januari 2018)
Resmi, Siti. 2014. Perpajakan Teori dan Kasus. Buku 1 Edisi 8. Jakarta: Salemba Empat

Sepang, Dkk. 2014. Perhitungan pencatatan dan pelaporan pajak pertambahan nilai Pada PT. Simple Jaya Manado, (Online), Vol.2, No.2,(https://e journal.

unsrat.ac.id/index.php/emba/article/vie w/4725, diakses 23 januari 2018)

Undang-Undang Republik Indonesia No.42 tahun 2009 tentang Pajak Pertambahan Nilai dan Pajak Penjualan Barang Mewah. Jakarta.

Waluyo. 2010. Perpajakan Indonesia. Jakarta: Salemba Empat.Bardach, Eugene. (2004). Practical Guide For Policy: Analysis: Eighfild Paths toward Problem Solving, CQ Press, NY

Budiman Rusli. (2013). Kebijakan Publik: Membangun Pelayanan yang Responsif. Bandung: Hakim Publishing.Pustaka berupa jurnal ilmiah:

Fatmawati. (2016). Relationship Among Stakeholders for Solid Waste Management in Makassar. OSR Journal Of Humanities And Social Science (IOSR-JHSS) Volume 21, Issue 5, Ver. 5 (May. 2016) PP 18-23. 